\title{
Comparative Effect of Different Fertilizers on Various Growth Parameters of Lycopersicum esculantum
}

\author{
Parveen Gill $^{1}$ *, Dharambir Singh ${ }^{1}$, T. Ravi Kumar ${ }^{2}$, Praveen Kumar ${ }^{3}$ and R.K. Gupta ${ }^{1}$ \\ ${ }^{1}$ Department of Zoology, ${ }^{2}$ Department of Vegetable Science, \\ ${ }^{3}$ Department of Biochemistry, Chaudhary Charan Singh Haryana Agricultural University, \\ Hisar, Haryana 125004, India
}

*Corresponding author

\section{A B S T R A C T}

Keywords

Fertilizers,

Lycopersicum

esculantum

\section{Article Info}

Accepted:

04 December 2017

Available Online:

10 January 2018
Investigated the impact of different fertilizers i.e. cow dung, vermicompost and urea on growth parameters of tomato (Lycopersicum esculantum) in 16 pots. Pots in, first, second and third rows were treated with cow dung, urea and vermicompost respectively and fourth rows was kept as control, per pot one plant was grown and five different growth and yield parameters viz. height of plant, diameter of the stem, dry weight of plant, total weight of fruits and number of fruits per plant were recorded. Pots treated with vermicompost exhibited best overall growth in comparison to other treatments.

\section{Introduction}

The vermicompost is highly beneficial for soil in many ways like as a soil conditioner and fertilizer, it promotes better physical and chemical properties of soil in addition to supplying various nutrients.

The water holding capacity and soil aeration is improved due to its more organic content. Nutrients present in vermicomposts are readily available and their absorption is easy for improving plant growth, it promotes better root growth. Vermicompost induces mulching effect and enhance the nutrients status of soil with micro and macro-nutrients and it also improves soil texture thereby reducing soil compaction.

Vermicompost as organic fertilizer enhances germination, induces plant growth, boost immunity and thus increases overall crop yield (Gajalaksmi and Aabbasi, 2004). The yield of tomato increases with vermicompost combined with $50 \%$ of the recommended inorganic fertilizers (Kolte et al., 1999). 
Various organic wastes of different origin such as sewage sludge, animal manure, and agro-industrial wastes have been used as vermicompost source (Suthar, 2009).

\section{Materials and Methods}

The impact of various types of fertilizers i.e. urea, vermicompost and cow dung were studied on growth parameters of tomato $(L$. esculantum).

\section{Treatments}

First row - four pots with cow dung

Second row - four pots with urea

Third row - four pots with vermicompost

Fourth row - four pots were kept without any treatment (control)

Five growth parameters per plant were recorded for tomato

Height of the plants in centimeters was measured by meter tape at maturity stage.

Diameter of the main stem measured in centimeters by Vernier Calliper from $2.5 \mathrm{~cm}$ above the ground level at the maturity stage.

Dry weight in grams of the whole plant (except fruit and roots) were weighed after harvesting by dehydrated in an oven at $60 \pm 5^{\circ} \mathrm{C}$.

Number of fruits per plant (well grown fruits) were handpicked and counted.

Total weight of fruits per plant was recorded at maturity.

\section{Results and Discussion}

It is considerable thrust for the research devoted to evaluate the effects of compost on plant growth and soil properties. The enhanced growth observed in plants may be attributed to the presence of more amount of available nitrogen in vermicompost. During the present investigation the effect of different fertilizers viz: vermicompost (Cow dung + kitchen waste), urea and cow dung were studied on growth parameters of tomato. The growth characteristics /parameters of the tomato are summarized in figure number $1,2,3,4$ and 5 .

Figure 1 and 2 depict that growth in terms of gain in plant height at harvest differ significantly in different treatments and it was maximum $(58.27 \mathrm{~cm})$ in vermicompost treated pots followed by 47.91 and $36.03 \mathrm{~cm}$ in urea $\&$ cow dung respectively whereas $27.30 \mathrm{~cm}$ in control. Stem diameters was also maximum $(1.13 \mathrm{~cm})$ in vermicompost treated pot followed by $0.94,0.83$ and $0.65 \mathrm{~cm}$ in urea, cow dung and control respectively.

Figure 3 and 4 shows that the maximum number of fruit per plant (15.71) in vermicompost treated pot followed by 11.99 , 9.64 and 6.83 in urea, cow dung and control respectively. The maximum weight gain in fruit was $73.72 \mathrm{gm}$ in vermicompost treated pot followed by $67.05 \mathrm{gm}$ in urea, $58.29 \mathrm{gm}$ in cow dung and $45.53 \mathrm{gm}$ in control. The study of Cheema et al., (2001) found that the number and weight of fruits increase because of adding of nitrogen and phosphorus one by one. The superior growth of crop because of nitrogen fertilizer observed by Hocking et al., (2003).

Maximum dry matter yield $44.23 \mathrm{gm}$ was observed in vermicompost treated pot followed by $36.54 \mathrm{gm}$ in urea, $33.28 \mathrm{gm}$ in cow dung and $31.55 \mathrm{gm}$ in control (Fig. 5). The outcomes of the present investigation revealed that the recommended dose of vermicompost resulted in maximum number of fruits followed by chemical fertilizer and cow dung per plants and minimum number of fruits in control. 


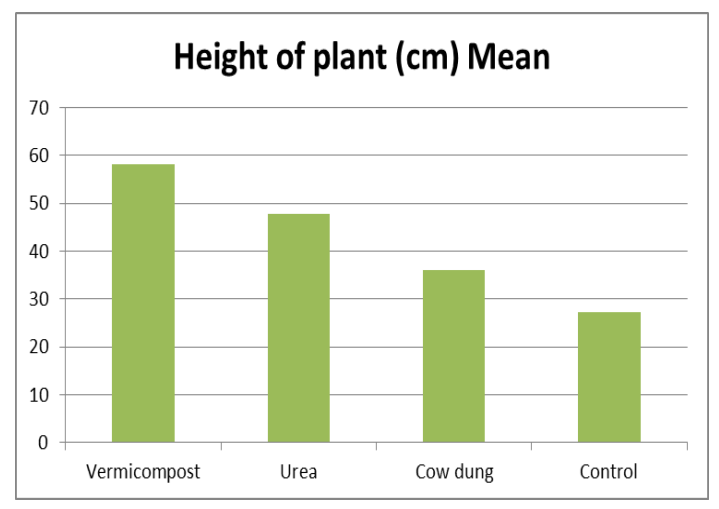

Fig.1 Average height of tomato plant in different fertilizers

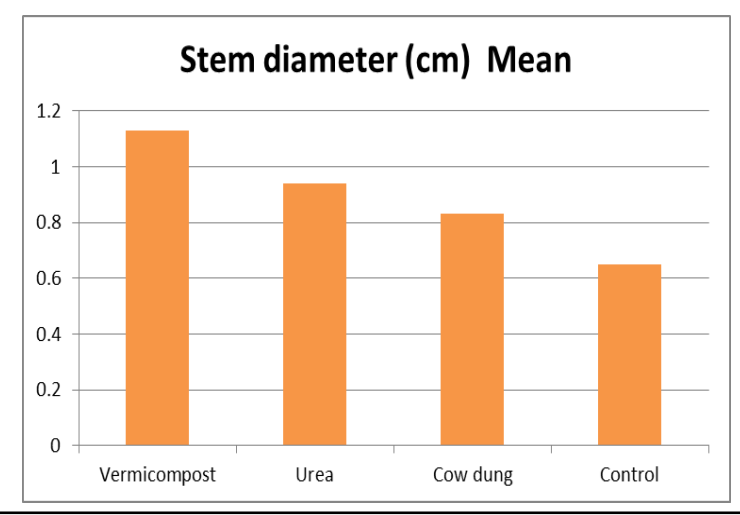

Fig.2 Average stem diameter of tomato plant in different fertilizers

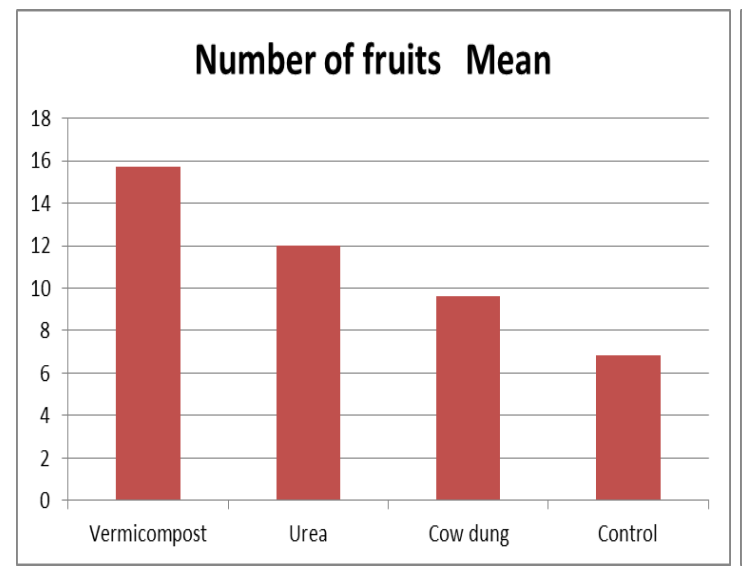

Fig.3 Average number of fruit of tomato plant in different fertilizers

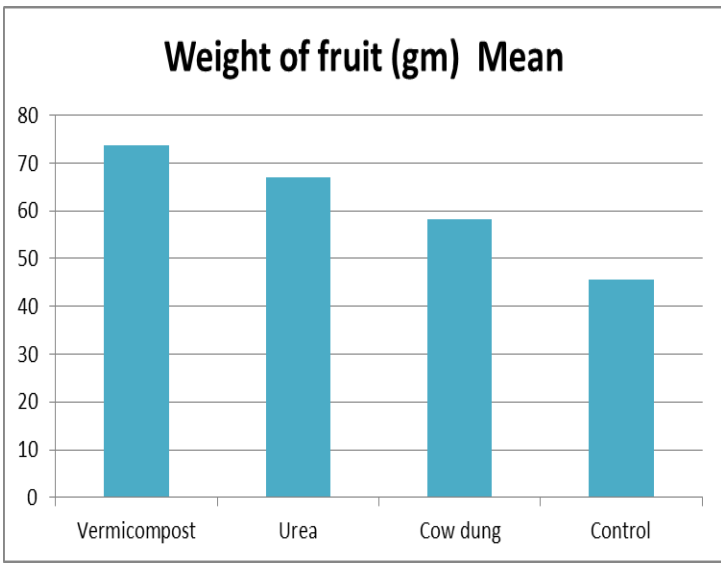

Fig.4 Average weight of fruit of tomato plant in different fertilizers

Fig.5 Average dry weight of tomato plant in different fertilizers

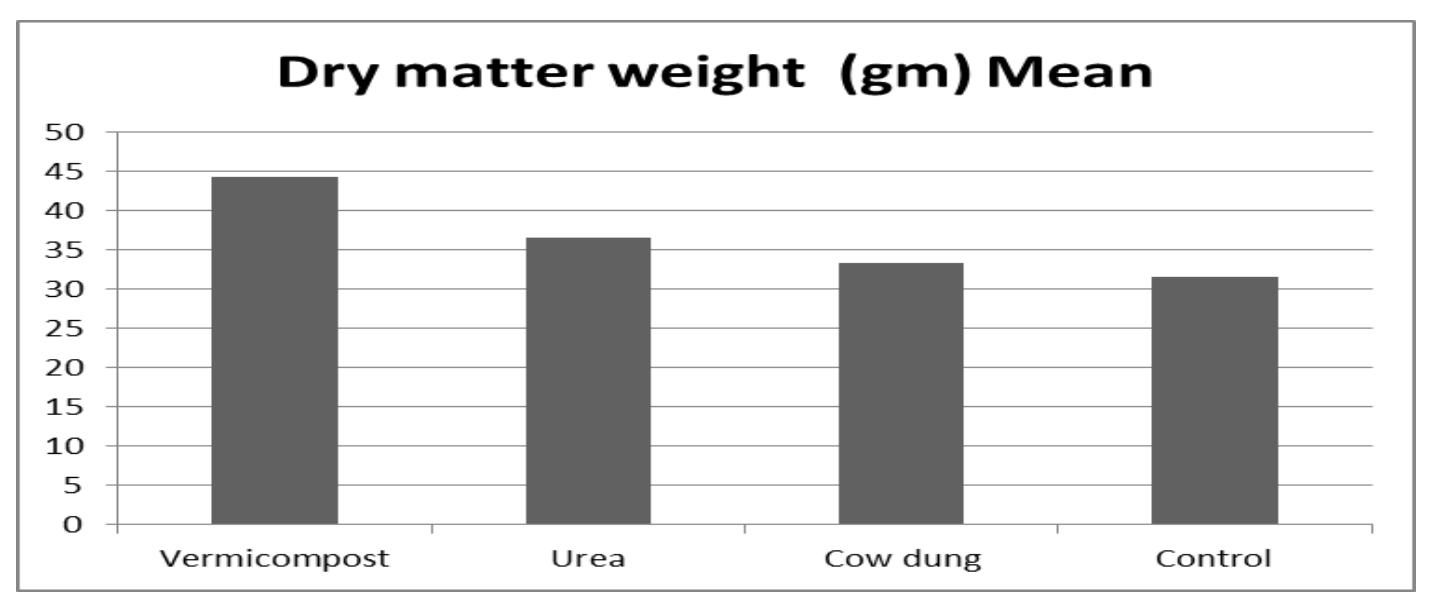


The findings are in agreement with those of Patil et al., (1998) who also worked on impact of fertilizers and vermicompost on crop yield. The growth in terms of gain in plant height, number of fruits, stem diameter, yield per plant and weight of fruit per plant significantly increases with vermicompost in comparision to plants treated with other fertilizers. Similar type of results was observed by Mehla et al., (1999).

The increase in vegetative growth with use of vermicompost might have been due to rapid conversion of carbohydrates into protein which in turn increased protoplasmic content and size of the cell. One of the fertilizer i.e nitrogen being important constituent of chlorophyll, amino acid, protein and nucleic acid must have enhanced cellular multiplication and elongation and ultimately shoot elongation.

The obtained data from present trial for tomato makes it clear that vermicompost is a superior fertilizer in comparison to all other treatments and increased the vegetative growth and yield per plant. This may be due to ability of the vermicompost to act as microbial agent (various types of bacteria) which improves soil health, boost immunity and makes easy accessibility of the nutrient to the vegetable plants. These findings are in accordance with Vadiraj et al., (1998); Subler et al., (2000) and Pal (2002).

The studies of Weber et al., 2007 shown that adding of compost enhance the physical properties of soil by reducing the bulk density and rising the water holding capacity of soil. Likewise, some studies shows that vermicomposting leachates or vermiwash used as substrate amendments or foliar sprays, for the better growth of tomato plants (Tejada et al., 2008), and strawberries (Singh et al., 2010).
The detrimental effect of chemical fertilizers on human health by plants is increasing day by day. To overcome from this problem there is alternating option that is vermicompost instead of chemical fertilizers because it has no harmful effect on human as well as other organisms. So from the present investigation it is concluded that vermicompost improves plant growth parameters as compare with other treatment of fertilizers.

\section{References}

Cheema, M.A., Malik, M.A., Hussain, A., Sah SH., and Basra. 2001. Effects of time and rate of nitrogen and phosphorus application on the growth and the seed and oil yields of Canola (Brassica napus L.). Jr. of Agron. Crop. Sc. 186(2): 103-110.

Gajalaksmi, S., and K.A, Aabbasi.2004. Earthworms and Vermicomposting, India njournal of Biotechnology, 3: 486494.

Hocking, P.J., Mead, J.A., Good, A. J., and Diffey, SM. 2003. The response of Canola (Brassica napus L.) to tillage and fertilizer placement in contrasting environments in Southern New South Wales. Aust. J. of Exp. Agriculture, 43(11): 1323-1335.

Kolte, U.M., Patil, A.S., and Tumbarbe, A.D. 1999. Response of tomato crop to different modes of nutrient input and irrigation. Journal of Maharashtra Agricultural Universities, 14:(1): 4-8.

Mehla, C.P., Srivastava, V.K., Mangat, R., and Singh, J. 1999. Stidies on some phonological growth parameters and yield of tomato as affected by variety fertilization and spacing. Agriculture Science Digest. 19(3): 462-463.

Pal, N. 2002. Effect of NPK and vermicompost in tomato. M.Sc. (Agriculture) thesis. CCS Haryana Agricultural University, Hisar. 
Patil, M.P., Hulamani, S.I., and Patil M.G. 1998. Response of new tomato genotype megha to Integrated Nutrient Management. Advance in Agriciltural in India 8: 39-42.

Singh, R., Gupta, R.K., Patil, R.T., Sharma, R.R., Asrey, R., Kumar, A., and Jangra., K.K. 2010. Sequential foliar application of vermicompost leachates improves marketable fruit yield and quality of strawberry. Scientia Horticulturae. 125 (4), 785-788, 36, 2010.

Subler, S., Edwards, C.A, and Metzer, T. 2000. Vermicomposting research and Education. Biocycle: 54-56.

Suthar, S. 2009. "Vermicomposting of vegetable -market solid waste using Eisenia fetida: Impact of bulking material on earthworm growth and decomposition rate" Ecological
Engineering, 35: (5): 914-920.

Tejada, M., Gonzalez, JL., Hernandez, M.T., and Garcia, C. 2008. Agricultural use of leachates obtained from two different vermicomposting processes. Bioresource Technology. 99: (14):62286232.

Vadiraj, B.A., Sddagaih, and Narajano, Poti. 1998. Effect of vermicompost on growth and yield of turmeric. South Indian Horticulture 46(3-4):176-179.

Weber, J., Karczewska, A., Drozd, J., Licznar, M, Licznar, S., Jamroz, E, \& Kocowicz, A. 2007. Agricultural and ecological aspects of a sandy soil as affected by the application of municipal solid waste composts. Soil Biology and Biochemistry. 39: 1294-1302.

\section{How to cite this article:}

Parveen Gill, Dharambir Singh, T. Ravi Kumar, Praveen Kumar and Gupta, R.K. 2018. Comparative Effect of Different Fertilizers on Various Growth Parameters of Lycopersicum esculantum. Int.J.Curr.Microbiol.App.Sci. 7(01): 56-60.

doi: https://doi.org/10.20546/ijcmas.2018.701.008 